\title{
Specific aspects of the dental restorative treatments in premolars
}

\author{
Particularităţile tratamentelor restauratoare odontale la premolari
}

\section{Irina-Maria Gheorghiu', Paula Perlea², Alexandru A. Iliescu³, Sânziana Scărlătescu4 Anca-Nicoleta Temelcea ${ }^{5}$}

\author{
${ }^{1}$ Disciplina de Odontoterapie Restauratoare, Facultatea de Medicină Dentară, \\ Universitatea de Medicină şi Farmacie „Carol Davila“, Bucureşti, România \\ ${ }^{2}$ Disciplina de Endodonţie, Facultatea de Medicină Dentară, \\ Universitatea de Medicină şi Farmacie „Carol Davila“, Bucureşti, România \\ ${ }^{3}$ Disciplina de Reabilitare Orală, Facultatea de Medicină Dentară, Craiova, România \\ ${ }^{4}$ Disciplina de Endodonţie, Facultatea de Medicină Dentară, \\ Universitatea de Medicină şi Farmacie „Carol Davila“, Bucureşti, România \\ ${ }^{5}$ Disciplina de Tehnică Dentară, Facultatea de Moaşe şi Asistenţă Medicală, \\ Universitatea de Medicină şi Farmacie „Carol Davila“, Bucureşti, România
}

\begin{abstract}
This article reviews the therapeutic approaches of the premolars and highlights the special aspects of the dental restorative treatments in premolars. The direct restoration of the coronal hard tissues loss in premolars is conditioned by several aspects involved, such as: topographic localization on the dental arches, aesthetical requirements, the association of different coronal dental lesions. A characteristic aspect of the premolars direct resin composite restorations is the phenomenon of cuspal flexure; the causes, consequences, as well as the ways of its prevention are presented in the article.
\end{abstract}

Keywords: premolar, restorative treatment, resin composites, cuspal flexure

\section{REZUMAT}

Articolul de faţă trece în revistă modalităţile de abordare terapeutică ale premolarilor şi pune în evidenţă particularităţile tratamentelor restauratoare odontale ale acestora. Restaurarea directă a pierderii de substanţă dură dentară la nivelul premolarilor este condiţionată de multiple aspecte implicate, între care se menţionează: localizarea topografică în cadrul arcadelor dentare, cerinţele fizionomice, asocierea frecventă a mai multor tipuri de leziuni coronare cu lipsă de substanţă. Un aspect caracteristic al restaurărilor odontale cu răşini compozite la premolari îl reprezintă fenomenul de flectare cuspidiană, fiind prezentate cauzele, consecinţele, precum şi modalităţile de prevenire ale acestuia

Cuvinte cheie: premolar, tratament restaurator, răşină compozită, flectare cuspidiană

\section{INTRODUCERE}

Premolarii sunt dinţi situați în zona laterală a arcadelor dentare, între canini şi primii molari. Cronologia erupției pentru dinţii premolari este cuprinsă între 9-12 ani, cu diferențe legate de sex în privința apariției primului premolar maxilar. Coroanele dentare ale premolarilor au un volum inter- mediar, mai mare decât al dinților frontali, dar mai mic decât al molarilor. Prezintă o față ocluzală, alcătuită din doi cuspizi bine exprimați, cu ajutorul cărora premolarii îşi exercită rolul în cadrul dentiției. Morfologia coronară specifică premolarilor precum şi topografia acestora în cadrul arcadelor dentare reprezintă factori ce determină aspecte par- 
ticulare ale tratamentelor restauratoare la premolari (1).

Patologia odontală cu care ne confruntăm la nivelul acestui grup de dinți este legată de: procese carioase şi complicațiile acestora; afectarea prin leziuni de uzură dentară: abfracție, eroziune, leziuni abrazive; traumatisme dentare coronare sau corono-radiculare (2).

Abordarea terapeutică a premolarilor constă în:

- Tratamente restauratoare odontale, ce vizează refacerea pierderii de substanță dură dentară, indiferent de cauzele acesteia; aceasta se poate realiza cu ajutorul restaurărilor directe sau prin mijloace protetice;

- Tratamente endodontice, când a apărut o implicare a țesutului pulpar sau a teritoriului apical, consecutiv cariei sau altor tipuri de leziuni de etiologie necarioasă;

- Tratamentul chirurgical: intervenții chirurgicale complementare terapiei conservatoare endodontice, care sunt utilizate în cazul patologiei periapicale; o altă categorie de intervenții chirurgicale, de aceasta dată radicale, sunt extracțiile, atunci când dintele respectiv este irecuperabil.

\section{Particularitățile tratamentelor restauratoare odontale la premolari}

Tratamentele restauratoare odontale la premolari prezintă o serie de particularități clinice care sunt prezentate în continuare.

Distrucțiile dentare coronare apar, la premolari, de cele mai multe ori, prin evoluția în suprafaţă şi profunzime a proceselor carioase, dar un tip frecvent de patologie o reprezintă coexistența cariilor dentare cu fenomenele de abfracție sau uzură dentară (leziuni abrazive vestibulare). Asocierea celor două procese de pierdere de țesut dur conduce la necesitatea unor restaurări complexe extinse şi voluminoase, dar care trebuie să îndeplinească criterii de estetică şi rezistență mecanică în acelaşi timp.

Restaurările dentare directe la nivelul premolarilor sunt realizate atunci când gradul distrucției o permite, cu ajutorul materialelor moderne de restaurare, răşinile compozite fiind materialul de elecție.

Refacerile coronare ale dinţilor premolari prin obturații sunt condiţionate de morfologia coronară specifică acestora: îndeosebi premolarii maxilari prezintă cuspizi accentuați şi şanț intercuspidian profund, aceste aspecte conducând la scăderea rezistenței la fractură coronară a dintelui respectiv. Restaurările odontale ce vizează pierderile extinse de țesut dentar, cu materiale compozite, pot declanşa apariția fenomenului de flectare cuspidiană. Ca atare, alegerea răşinii compozite trebuie să se facă selectiv, pentru fiecare zonă ce urmează a fi restaurată, în asociere cu alegerea unei tehnici de lucru care să reducă stresul asupra pereților restaurării coronare.

Primul aspect ce caracterizează restaurările odontale directe la premolari care trebuie menționat este faptul că, datorită poziţionării în cavitatea bucală, abordarea premolarilor se face cu uşurință. Vorbim de porțiunea anterioară a zonelor laterale ale arcadelor dentare, vizibilă direct şi accesibilă tuturor manoperelor terapeutice necesare. $\mathrm{Ca}$ atare, restaurările coronare directe se pot realiza corect, cu îndeplinirea tuturor standardelor de calitate ale refacerilor pierderilor de substanță dentară.

Un alt doilea aspect legat de terapia premolarilor este faptul că poziția lor vizibilă implică obligatoriu materiale de restaurare fizionomice, îndeosebi materiale compozite.

Cerințele estetice impuse răşinilor compozite sunt:

- stabilitate coloristică;

- fotomimetism;

- disponibilitate într-un număr mare de nuanțe coloristice;

- posibilităţile de finisare crescută, ceea ce conferă un aspect natural materialului de restaurare şi cresc rata de supraviețuire a restaurării în cavitatea bucală, prin faptul că placa dentară bacteriană nu aderă la suprafețele netede, neretentive $(5,6)$.

Mai mult decât în orice altă zonă a arcadelor dentare, la nivelul premolarilor, proprietățile mecanice ale materialelor de restaurare (rezistență la fractură, rezistență la abraziune, modulul de elasticitate, contracția de polimerizare etc.) trebuie să coexiste în aceeaşi proporție cu proprietăţile estetice necesare unor restaurări din zone vizibile $(3,4)$.

Pierderea de substanță dură dentară localizată în treimea cervicală a feței vestibulare a premolarilor este frecvent întâlnită şi se prezintă sub aspectul clinic de leziune de abfracție sau leziune abrazivă. Leziunile de abfracție sunt cauzate de forțele ocluzale excesive care sunt transmise în zona cervicală. 


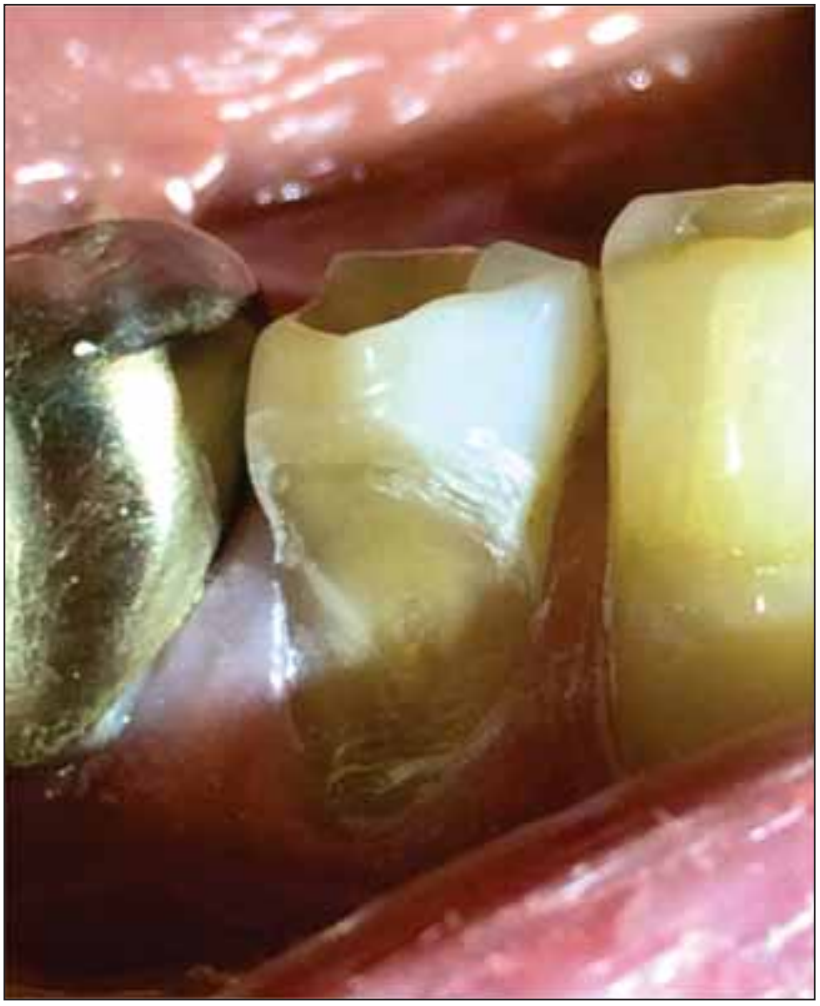

FIGURA 1. Aspectul clinic al leziunii de abfractie localizată pe premolarul secund mandibular

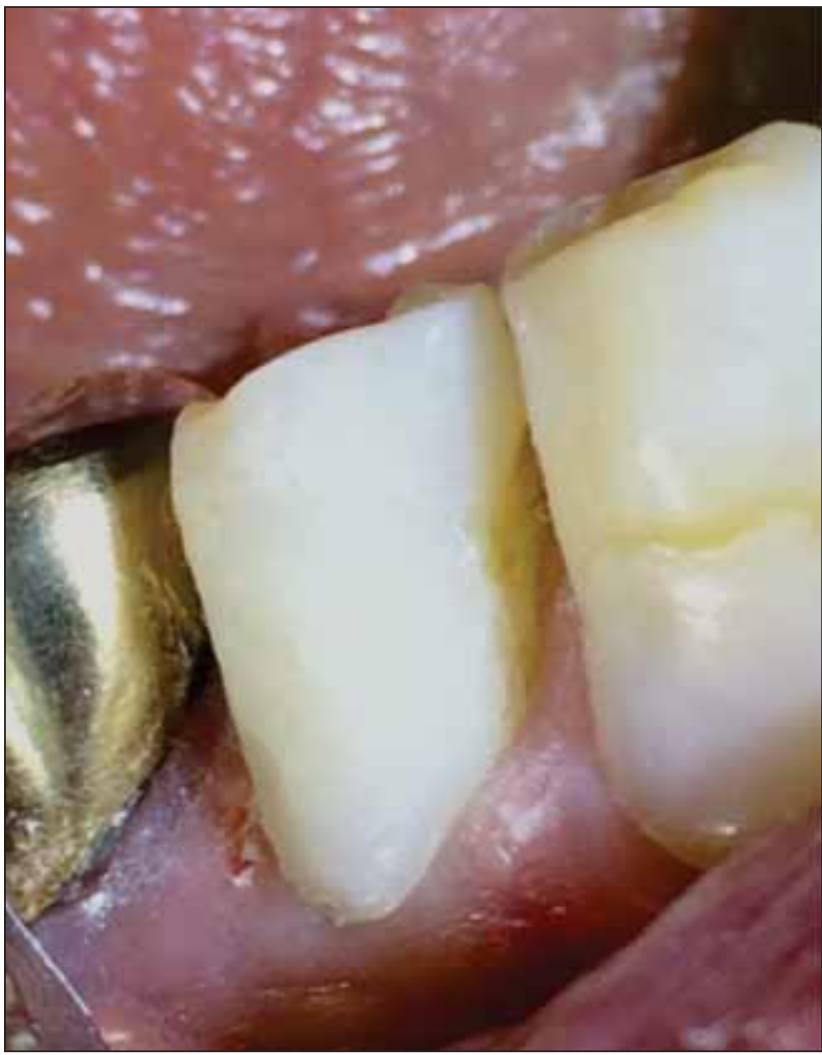

FIGURA 2. Tratamentul restaurator odontal cu răşini compozite al leziunii de abfracție de la nivelul premolarului secund mandibular

În această regiune, forțele orizontale determină ruperea legăturilor dintre cristalele de hidroxiapatită, cu apariția fracturilor la nivelul prismelor de smalț. Restaurările directe ale acestui tip de leziune impun alegerea unor răşini compozite cu contracție mică de polimerizare şi modul de elasticitate scăzut, care permit deformarea obturației odată cu structurile dentare, fără pierderea adeziunii la țesuturile dure dentare.

Leziunile cervicale abrazive apar în cele mai multe situații ca urmare a unui periaj dentar incorect sau intempestiv. În acelaşi timp, pentru a asigura succesul restaurărilor cervicale directe la nivelul premolarilor, identificarea şi înlăturarea factorului etiologic este esențială. În cazul leziunilor de abfractie se impune eliminarea traumei ocluzale responsabilă de apariţia defectului cervical. În situaţia leziunilor abrazive vestibulare cervicale, este obligatorie educarea pacientului în privinţa tehnicii corespunzătoare de periaj dentar pentru prevenirea recidivelor.

Etapele de lucru pentru restaurările coronare cu materiale compozite sunt:

- Evaluarea gradului de distrucție coronară, detectarea factorului etiologic şi identificarea posibilităților de restaurare (prin obturație sau protetică) la care se pretează dintele respectiv. În acest sens, se iau în considerare şi factorii locali asociați care pot influența rezultatul restaurării: prezența parafuncțiilor, gradul de igienă şi de interes pentru sănătate dentară, evaluarea arcadei antagoniste etc.

- Realizarea preparației pentru inserarea obturației din răşini compozite; acesta începe cu determinarea culorii răşinii ce va fi utilizată, urmată de preparația propriu-zisă: îndepărtarea în totalitate a țesuturilor alterate, pe principiul minim invaziv, cu abordarea cât mai conservatoare a țesuturilor restante; finisarea marginilor cavității;

- Etapa de realizare a cavității este urmată de cea de tratament a plăgii dentinare, în conformitate cu situația clinică respectivă;

- Realizarea adeziunii la smalț şi dentină, conform protocoalelor specifice tipului de adeziv utilizat;

- Inserarea răşinii compozite în cavitate, adaptarea şi polimerizarea sa;

- Adaptarea şi finisarea restaurării din materiale compozite. 
Un fenomen care poate apărea la nivelul restaurărilor odontale voluminoase cu răşini compozite ale premolarilor este cel de flectare cuspidiană şi, ulterior, posibilitatea de fractură a pereților cavității. Această situație specială, întâlnită cu probabilitate mai mare la premolarii superiori, se referă la restaurările voluminoase, unde pereții vestibulari şi orali restanți sunt foarte subțiri (spre exemplu tip mezio-ocluzo-distal) (Fig. 3).

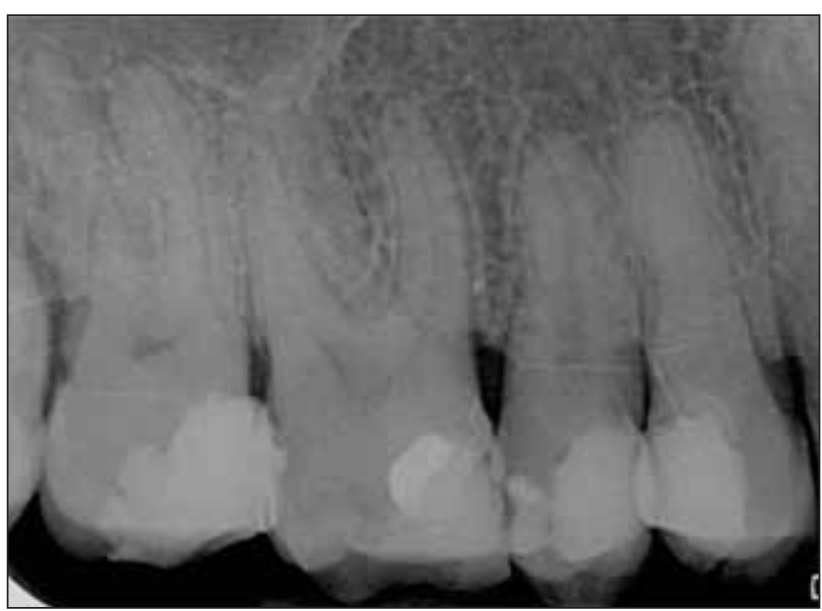

FIGURA 3. Imaginea radiologică a restaurărilor odontale masive cu răşini compozite la nivelul premolarilor maxilari, incorect adaptate, cu risc de fractură a pereților coronari.

Deformările cuspizilor pot produce fisuri la nivel cervical, în zona de minimă grosime şi rezistență, fiind urmate de fracturi ale acestor pereți $(7,8)$. Acest fenomen este accentuat când restaurarea unei cavităţi ocluzale sau mezio-ocluzo-distale de întindere şi profunzime mare este asociată cu restaurarea leziunilor cervicale, practic când este vorba de o cavitate compusă ce cuprinde o mare parte din volumul sau suprafața coronară a dintelui respectiv. Abordarea actuală minim invazivă şi conservatoare în odontoterapia restauratoare nu mai presupune scurtarea pereților până în zona în care grosimea lor va oferi suficientă rezistență construcției, aşa cum se făcea conform regulilor lui Black (regula de rezistență în prepararea cavității) pentru materiale neadezive.

În condițiile în care cantitatea de răşină compozită este mare, prin contracția de priză a acesteia se poate produce fisurarea şi, ulterior, fractura coronară în zona de rezistență critică. La acest aspect contribuie şi morfologia coronară a premolarilor superiori, cu aspect cilindric şi cuspizi ascuțiţi, proeminenți, dar cu dimensiune vestibulo-orală mică şi separate printr-un şanț intercuspidian adânc.
Acest fenomen se întâlneşte frecvent atunci când restaurările se efectuează cu răşini compozite autopolimerizabile, a căror contracție de priză dezvoltă forțe centripete înspre masa obturației, care, practic, reprezintă sursa de apariţie a micro-fisurilor coronare cervicale. De asemenea, fenomenul este prezent atunci când restaurările sunt realizate cu răşini compozite fotopolimerizabile, în care cantitatea de răşină este foarte mare (practic, nu se utilizează cimenturile cu ionomeri de sticlă ca substitut pentru dentină) (9).

Pentru a preveni apariția acestui fenomen sunt indicate şi utilizate următoarele tipuri de abordări terapeutice:

- Restaurarea prin tehnica „sandwich“: sunt refaceri complexe formate din răşini compozite şi cimenturi cu ionomeri de sticlă; în aceste restaurări, cimentul cu ionomeri de sticlă înlocuieşte şi prezintă proprietăți asemănătoare cu ale dentinei, iar răşina compozită reface smalțul. Astfel se realizează o obturaţie care reproduce țesuturile dentare, $\mathrm{cu}$ proprietățile lor specifice; acest tip de restaurare este o stuctură monolitică, ce are o durată mare de supraviețuire în cavitatea bucală, iar cantitatea mică de răşină compozită utilizată face ca fenomenul de flexie cuspidiană să fie diminuat;

- Utilizarea materialelor compozite moderne care au o contracție de polimerizare redusă şi modul de elasticitate scăzut, care le conferă flexibilitate crescută;

- Tehnica adecvată de inserare a răşinii compozite în interiorul cavităţii, astfel încât vectorul de contracție al polimerizării să nu determine microfisuri de smalț şi dentină în zonele cu rezistență diminuată.

O altă particularitate a tratamentelor restauratoare odontale la premolari apare în privința refacerilor coronare ale premolarilor la care s-a efectuat un tratament endodontic. Din cauza incidenței mari de afectare prin carie şi traumatisme penetrante, rata de efectuare a tratamentelor endodontice la premolari, îndeosebi la primul premolar superior, este şi ea mare (10). Dincolo de necesitatea efectuării unui tratament endodontic corect, în timp, apar următoarele aspecte:

- modificarea culorii coroanei premolarului prim devitalizat (discromia dentară), cu afec- 
tarea directă a aspectului fizionomic; se vor impune aşadar tratamente de albire a dinţilor devitali, fie conservatoare (albirea internă), fie prin acoperire cu fațete sau chiar microproteze dentare.

- modificarea parametrilor fizici (mecanici) ai structurilor restante devitalizate, care devin, în timp, mai puțin rezistențe la forțele ocluzale; în asociere cu restaurările voluminoase (pierderea mare de substanță dură dentară a condus la necesitatea extirpării vitale), apare riscul de fractură a pereților dentari existenți $(11,12)$.

Odată cu pierderea adaptării marginale a restaurărilor coronare şi apariţia recidivelor de carie şi a cariilor secundare, din cauza topografiei şi morfologiei coronare, chiar la nivelul premolarilor vitali, riscul de fracturi ale pereților restanți este considerabil $(13,14)$ ( Fig. 4).

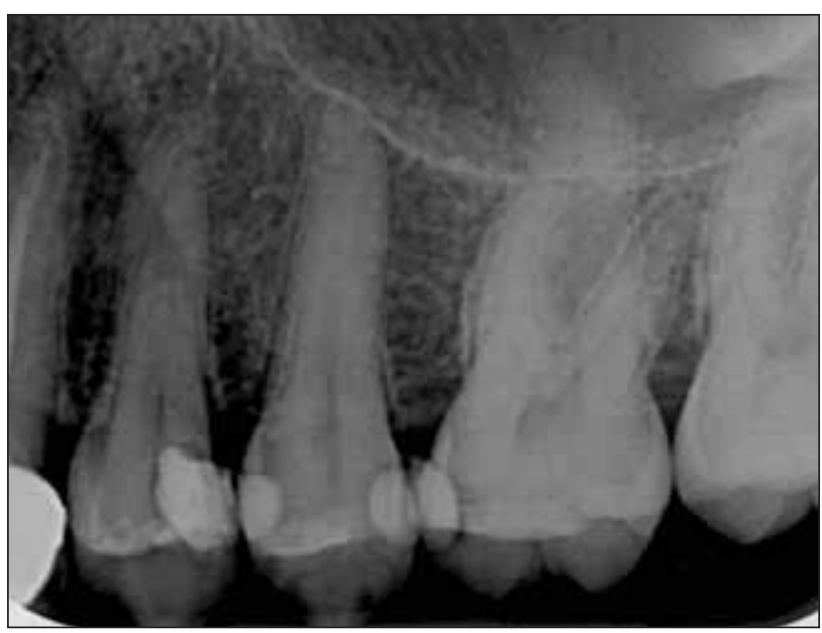

FIGURA 4. Imaginea radiologică a restaurărilor coronare cu răşini compozite la nivelul premolarilor maxilari, ce prezintă recidive şi carii secundare marginale

Refacerile pierderilor de substanță dură dentară coronară la premolari se pot realiza şi prin incrusta- ții din materiale compozite sau ceramice (cerințele estetice contraindică, cel puțin la premolarii superiori, restaurările prin incrustații metalice). O altă modalitate de restaurare coronară specifică premolarilor este cea protetică, cu ajutorul microprotezelor, în asociere cu ancoraj intraradicular cu reconstituiri corono-radiculare turnate sau, modern, din fibre de sticlă. Aceasta este metoda de elecție atunci când distrucțiile coronare sunt importante şi nu mai pot fi refăcute corect prin metodele descrise anterior. Tipurile de microproteze fizionomice utilizate sunt: coroane metalo-ceramice, coroane integral ceramice, coroane ceramice pe suport de zirconiu. Atunci când situația financiară a pacientului nu permite, din păcate, aceste tipuri de microproteze fizionomice, se pot utiliza coroane semifizionomice din aliaj crom-nichel, cu fațete din acrilat sau material compozit.

\section{CONCLUZII}

Restaurările directe odontale la premolari sunt realizate cu ajutorul materialelor moderne, răşinile compozite fiind materialul de elecție. Particularitățile tratamentelor restauratoare odontale la premolari sunt legate de tiparul şi asocierea leziunilor ce conduc la pierderea de substanţă, precum şi de morfologia coronară specifică. Conceperea şi realizarea corectă a restaurărilor în privința preparației dintelui, a alegerii materialului şi a tehnicii de lucru corespunzătoare, vor conduce la rezultate excelente.

\section{Mențiune}

Toți autorii au contribuție egală în realizarea acestui articol.

\section{Conflict of interest: none declared} Financial support: none declared

material selection to minimise fracture. Dent Mater. 2007; 23 (12):1562-9.

5. Popa M.P., Bodnar D., Varlan M.C. Manual de Odontoterapie Restauratoare, Editura Universitară Carol Davila, Bucureşti, 2006.

6. Bartlett DW, Shah P. A critical review of non-carious cervical (wear) lesions and the role of abfraction, erosion, and abrasion. J Dent Res. 2006; 85(4):306-12.

7. González-López S., Lucena-Martín C., de Haro-Gasquet F., Vilchez-Díaz M.A., de Haro-Muñoz C. Influence of
3. Gheorghiu I. Complicațile cariei dentare. Editura Universitară Carol Davila, Bucureşti, 2014.

4. Ichim I.P., Schmidlin P.R., Li Q., Kieser J.A., Swain M.V. Restoration of non-carious cervical lesions Part II. Restorative 
different composite restoration techniques on cuspal deflection: an in vitro study. Oper Dent. 2004 Nov-Dec; 29(6):656-60.

8. González-López S., Vilchez Díaz M.A., de Haro-Gasquet F., Ceballos L., de Haro-Muñoz C. Cuspal flexure of teeth with composite restorations subjected to occlusal loading. J Adhes Dent. 2007 Feb; 9(1):11-5.

9. Asmussen E., Peutzfeldt A. Polymerization contraction of resin composite vs energy and power density of light-cure. Eur J Oral Sci 2005; 113(5):417-421.

10. Heffernan M., Martin W., Norton D. Prognosis of endodontically treated teeth? Quint Int 2003, 34(7):558-560.

11. Mynampati P., Babu M.R., Saraswathi D.D., Kumar J.R., Gudugunta L., Gaddam D. Comparison of fracture resistance and failure pattern of endodontically treated premolars with different esthetic onlay systems: An in vitro study. J Conserv Dent. 2015 Mar-Apr; 18(2):140-3.

12. Bitter K., Meyer-Lueckel H., Fotiadis N., Blunck U., Neumann K., Kielbassa A.M. Influence of endodontic treatment, post insertion, and ceramic restoration on the fracture resistance of maxillary premolars. Int Endod J. 2010; 43:469-77.

13. Mjör I.A., Toffenetti F. Secondary caries: a literature review with case reports. Quint Int 2000; 31(3):165-79.

14. De Munk J., Van Landuyt K.L., Coutinho E. Fatigue resistance od dentin/composite interfaces with an additional intermediate elastic layer. Eur J Oral Sci 2005; 113:77-82. 